\title{
EFEKTIFITAS LAYANAN PENGUASAAN KONTEN MENGGUNAKAN MODEL PEMBELAJARAN ROLE PLAYING UNTUK MENINGKATKAN KEPERCAYAAN DIRI SISWA DALAM BELAJAR” (Studi Eksperimen terhadap Siswa SMAN 2 Padang)
}

\author{
Venna Deski Arienta ${ }^{1)}$, Firman ${ }^{2)}$, Yeni Karneli ${ }^{3)}$ \\ Jurusan Bimbingan dan Konseling \\ FIP Universitas Negeri Padang \\ email: vennadeski123@gmail.com
}

\section{ABSTRAK}

Siswa dengan kepercayaan diri yang rendah cenderung mengalami hambatan dalam kehidupannya, terutama dalam proses pembelajaran. Salah satu upaya yang dilakukan guru BK untuk meningkatkan kepercayaan diri siswa dalam belajar yaitu melalui layanan penguasaan konten. Namun pada kenyataanya, upaya yang diberikan guru BK belum mencapai sasaran sesuai yang diharapkan. Penelitian ini bertujuan untuk melihat efektivitas layanan penguasaan konten menggunakan model pembelajaran role playing untuk meningkatkan kepercayaan diri siswa dalam belajar di sekolah.

Penelitian ini menggunakan pendekatan kuantitatif. Jenis penelitian ini termasuk penelitian dengan rancangan Quasy-Experiment jenis The Non Equivalent Control Group. Tempat penelitian ini SMAN 2 Padang dengan subjek kelas $\mathrm{X}$ MIPA 5 dan X MIPA 6. Teknik pengumpulan data menggunakan kuesioner, kemudian dianalisis dengan teknik uji beda $(t$-test).

Berdasarkan hasil penelitian menunjukan layanan penguasaan konten menggunakan model pembelajaran role playing dapat meningkatkan kepercayaan diri siswa dalam belajar dan lebih efektif digunakan dibandingkan dengan layanan penguasaan konten tanpa menggunakan model pembelajaran role playing. Secara khusus temuan pada penelitian ini yaitu : (1) Terdapat perbedaan yang signifikan pada kepercayaan diri dalam belajar siswa kelompok eksperimen sebelum dan sesudah diberikan layanan penguasaan konten menggunakan model pembelajaran role playing, (2) Tidak terdapat perbedaan yang signifikan pada kepercayaan diri dalam belajar siswa kelompok kontrol sebelum dan sesudah diberikan perlakuan layanan penguasaan konten tanpa menggunakan model pembelajaran role playing, (3) Terdapat perbedaan yang signifikan pada kepercayaan diri siswa antara kelompok eksperimen dan kelompok kontrol. Hal ini menunjukan bahwa layanan penguasaan konten menggunakan model pembelajaran role playing efektif untuk meningkatkan kepercayaan diri siswa dalam belajar. Dengan demikian, guru bimbingan dan konseling diharapkan dapat meningkatkan kepercayaan diri siswa dalam belajar melalui layanan penguasaan konten menggunakan model pembelajaran role playing yang tentunya tidak terlepas dari bantuan pihak terkait.

Kata kunci : Layanan Penguasaan Konten, Model Pembelajaran Role Playing, Kepercayaan Diri dalam Belajar

\section{PENDAHULUAN}

Belajar merupakan salah satu faktor yang mempengaruhi dan berperan penting dalam pembentukan pribadi dan tingkah laku individu. Menurut Slameto (2010:2) belajar adalah suatu proses usaha yang dilakukan individu untuk memperoleh suatu perubahan tingkah laku yang baru secara keseluruhan, sebagai hasil pengalaman individu itu sendiri dalam interaksinya dengan lingkungannya. Untuk mencapai kesuksesan dalam belajar salah satu yang harus dimiliki adalah kepercayaan diri, yang merupakan modal dasar untuk meraih kesuksesan dalam belajar (Syaiful, 2010:47). Dalam kenyataannya, tidak semua siswa dapat mencapai tujuan dari proses belajar mengajar dengan baik. Beberapa siswa mendapat tantangan atau hambatan yang harus dihadapi, salah satu hambatan yang terjadi dalam proses belajar mengajar di kelas baik dalam masalah diri pribadi, belajar maupun sosial. Ketidakyakinan seseorang dalam tampil di depan umum masih sering terjadi, kurangnya kepercayaan diri menjadi salah satu penyebab hal tersebut.

Orang yang dikatakan memiliki kepercayaan diri ialah orang yang merasa puas terhadap dirinya dan yakin ia memiliki kemampuan yang dapat menghantarkannya mencapai suatu keberhasilan. Menurut Enung Fatimah (2006:149) kepercayaan diri adalah sikap positif seorang individu yang memampukan dirinya untuk mengembangkan penilaian positif, baik terhadap dirinya sendiri maupun terhadap lingkungan/situasi yang dihadapinya. Berbekal rasa percaya diri, peserta didik akan mampu mengembangkan potensi yang dimilikinya dan mencapai kesuksesan belajar.

Namun kenyataanya, masih terdapat siswa yang tidak percaya diri sehingga mengalami hambatan dalam kehidupannya terutama dalam proses pembelajaran di sekolah. Perasaan takut, cemas dan gelisah tak jarang mewarnai dan menghambat dalam proses belajar di kelas maupun dalam proses melakukan kontak dengan lingkungan sosialnya. Hal itu selaras dengan yang telah disampaikan oleh Supriyo (2008:47) bahwa krisis kepercayaan diri yang tidak segera diatasi akan menimbulkan: 1) tidak dapat bergaul dengan teman-teman lain secara wajar, 2) proses belajar menjadi terhambat, 3) kesulitan berkomunikasi, 4) pencapaian tugas perkembangan jadi terhambat, 5) terkucil dari lingkungan sosial, 6) mengalami depresi, dan 7) tidak berani melakukan perubahan.

\footnotetext{
${ }^{1}$ Venna Deski Arienta (1), Jurusan Bimbingan dan Konseling, Fakultas Ilmu Pendidikan Universitas Negeri Padang.

${ }^{2}$ Firman (2), Jurusan Bimbingan dan Konseling, Fakultas Ilmu Pendidikan Universitas Negeri Padang

${ }^{3}$ Yeni Karneli (3), Jurusan Bimbingan dan Konseling, Fakultas Ilmu Pendidikan Universitas Negeri Padang
} 
Berdasarkan data awal yang diperoleh, ciri-ciri tersebut ditemukan peneliti saat melakukan wawancara dengan guru BK SMA N 2 Padang pada 4 Oktober 2016 terkait masalah kurang percaya diri yang dialami siswa dalam belajar ini ditunjukkan dengan perasaan grogi saat tampil di depan kelas yang terlihat dari raut wajah dan langkah kaki siswa yang tidak mantap, siswa memiliki rasa malu yang berlebihan ketika menjadi pusat perhatian, siswa merasa malu menjadi diri sendiri karena merasa dirinya selalu memiliki kekurangan sehingga selalu berusaha untuk menjadi seperti orang lain dan tidak yakin terhadap potensi yang dimilikinya. Selain itu, dari hasil pengamatan penulis selama melaksanakan PLBK di SMA N 2 Padang, diketahui bahwa terdapat siswa yang tidak meyakini kemampuanya, takut gagal sebelum mencoba, grogi saat tampil di depan kelas dan enggan mengemukakan pendapat saat diberi kesempatan. Selanjutnya, keterangan dari hasil wawancara dengan siswa di SMA N 2 Padang pada 11 Oktober 2016, terungkap bahwa dalam kehidupan sehari-hari terutama dalam proses pembelajaran di kelas mereka ingin tampil dan berpartistipasi aktif, hanya saja mereka merasa kurang mampu, kurang didengarkan, dianggap tidak penting, dan merasa diabaikan ketika berpendapat, takut salah dan ragu dalam bertindak.

Dengan adanya hambatan-hambatan tersebut, sudah seharusnya untuk diberikan perhatian khusus dan penanganan segera dari pihak-pihak yang terlibat dalam proses pembelajaran sehingga siswa tidak mengalami hambatan dalam proses perkembangannya dan diharapkan dapat meraih prestasi yang optimal. Untuk guru bimbingan dan konseling dapat berupaya membantu siswa dengan melakukan kegiatan berupa layanan-layanan BK yang mengarah pada peningkatan kepercayaan diri siswa. Salah satu layanan yang dapat diberikan adalah layanan penguasaan konten. Menurut Prayitno (2012:89) layanan penguasaan konten (PKO) merupakan layanan bantuan kepada individu (sendiri ataupun kelompok) untuk menguasai kemampuan atau kompetensi tertentu melalui kegiatan belajar.

Dalam pemberian layanan, guru BK hendaknya dapat menyajikan dengan cara yang menarik, baik melalui penggunaan media, strategi maupun model pembelajaran sehingga dapat lebih mudah untuk merangsang siswa untuk menguasai dan menerapkan isi dari materi layanan. Model pembelajaran yang digunakan dalam hal ini adalah model pembelajaran role playing, yang merupakan model pembelajaran dimana individu memerankan situasi dalam kehidupan sehari-hari dengan tujuan untuk membantu tercapainya pemahaman diri sendiri, meningkatkan keterampilan-keterampilan, menganalisis prilaku atau menunjukan pada orang lain bagaimana prilaku seseorang atau bagaimana seseorang harus berprilaku.

Berdasarkan penelitian Kadek Suhardita (2011) menunjukkan bahwa terdapat perubahan yang signifikan percaya diri siswa setelah diberikan pelayanan penggunaan teknik permainan dalam bimbingan kelompok, dengan demikian dapat dikatakan bahwa penggunaan teknik permainan efektif digunakan untuk meningkatkan percaya diri siswa. Hasil penelitian Wardatul \& Ayom (2012) melalui tindakan kelas bimbingan dan konseling yang dilaksanakan dalam dua siklus menunjukan bahwa teknik sosiodrama efektif meningkatkan kepercayaan diri siswa.

Selanjutnya, dari penelitian Wirahanteng (2014) disimpulkan pelaksanaan layanan penguasaan konten dengan metode simulasi dapat meningkatkan percaya diri siswa. Pada siklus I peningkatan kepercayaan diri berbicara di depan kelas setelah diberi layanan pengusaan konten dengan metode simulasi, yang percaya diri menjadi 5 siswa $(33 \%)$ tinggi, 5 siswa (33\%) sedang dan 5 siswa (33\%) rendah. Sementara pada siklus II menjadi 13 siswa (87\%) tinggi, 2 siswa (13\%) sedang, dan tidak ada siswa yang kepercayaan dirinya rendah.

Dipilihnya layanan penguasaan konten dikarenakan dari pelaksanaan wawancara dengan guru BK sebelumnya, diketahui bahwa guru BK telah melaksanakan beberapa layanan untuk meningkatkan kepercayaan diri siswa dalam belajar, namun hasil dari perlakuan tersebut belum sesuai dengan yang diharapkan. Adapun dalam meningkatkan kepercayaan diri siswa dapat dilakukan melalui pemberian konten atau kemampuan khusus kepada siswa dengan melibatkan siswa secara aktif dalam pelaksanaanya, maka penulis memilih untuk melaksanakan layanan penguasaan konten dengan model pembelajaran role playing.

Berdasarkan uraian tersebut, sudah selayaknya sebagai guru BK di sekolah untuk menindaklanjuti permasalahan tersebut. Hal tersebut dikarenakan dapat menghambat proses belajar siswa. Sehingga dengan demikian peneliti tertarik untuk meneliti "Efektifitas Layanan Penguasaan Konten Menggunakan Model Pembelajaran Role Playing untuk Meningkatkan Kepercayaan Diri Siswa dalam Belajar".

\section{METODOLOGI}

Penelitian ini menggunakan pendekatan kuantitatif..Rancangan penelitian yang digunakan adalah Quasi-Experiment atau ekperimen semu yaitu suatu desain ekperimen yang memungkinkan peneliti mengendalikan variabel sebanyak mungkin dari situasi yang ada. Salah satu jenis Quasi-Experiment yang dipakai untuk penelitian adalah the non equivalent control group. Subjek penelitian meliputi kelas X Mipa 5 sebagai kelas eksperimen dan kelas X Mipa 6 SMA N 2 Padang sebagai kelompok kontrol yang masing-masing berjumlah 35 orang siswa. Untuk mengumpulkan data, digunakan instrumen penelitian berupa angket untuk pretest dan untuk posttest dengan alternative jawaban Sangat Sesuai (SS), Sesuai (S), Cukup Sesuai (CS), Tidak Sesuai (TS), dan Sangat Tidak Sesuai (STS). Untuk melihat perbandingan nilai Pretest dan Posttest yang dikemukakan oleh Suharsimi Arikunto (2010:395), dengan langkah-langkah sebagai berikut.

1. Melaksanakan Pretest (O1), cari skor dan ratarata hitungnya.

Jumlah skor ideal $=$ skor tertinggi $\mathrm{x}$ jumlah item angket x sampel

$$
\mathrm{P}=\frac{I}{N} \times 100
$$

Keterangan :

$\mathrm{P}:$ Persentase

$f$ : Frekuensi

$\mathrm{n}:$ Jumlah sampel 
2. Setelah data diolah menggunakan rumus statistik kemudian diterapkan kriteria penilaian masing-masing data yang diperoleh dengan mengacu pada batasan-batasan yang dikemukakan oleh Agus Irianto (2004:22) dengan rumus sebagai berikut:

Interval $_{\mathrm{k}}=\underline{\text { Data terbesar }- \text { data terkecil }}$ Jumlah kelompok

Berdasarkan hasil perhitungan yang telah dilakukan, peneliti menentukan kriteria pengolahan data deskriptif hasil penelitian sebagai berikut.

Tabel 1. Kriteria Pengolahan Data Deskriptif Hasil Penelitian

\begin{tabular}{|c|c|c|}
\hline $\begin{array}{c}\text { Kelas } \\
\text { Interval } \\
\text { Skor } \\
\text { Keseluruhan }\end{array}$ & Kategori & $\begin{array}{c}\text { \% Skor } \\
\text { Keseluruhan }\end{array}$ \\
\hline$\geq 159$ & $\begin{array}{c}\text { Sangat } \\
\text { Tinggi }\end{array}$ & $84-100$ \\
\hline $129-158$ & Tinggi & $68-83$ \\
\hline $99-128$ & Sedang & $52-67$ \\
\hline $68-98$ & Rendah & $36-51$ \\
\hline$\leq 67$ & $\begin{array}{c}\text { Sangat } \\
\text { Rendah }\end{array}$ & $\leq 35$ \\
\hline
\end{tabular}

Selanjutnya, untuk menguji perbedaan kepercayaan diri siswa dalam belajar sebelum dan setelah diberikan perlakuan, maka digunakan uji $\mathrm{t}$ atau $\mathrm{t}$-test. Tulus Winarsunu (2002:87) menyatakan untuk menguji signifikansi perbedaan dua buah mean yang berasal dari dua buah distribusi adalah dengan menggunakan teknik t-test dengan rumus sebagai berikut.

$$
t \text { test }=\frac{\bar{x}_{1}-\bar{x}_{2}}{\sqrt{\left.\frac{s D_{1}^{2}}{N_{1}-1}\right]+\left[\frac{s D_{2}^{2}}{N_{2}-1}\right]}}
$$

Keterangan,

$\bar{x}_{1}$ : Mean tingkat kepercayaan diri siswa eksperimen

$\bar{V}_{2}$ : Mean tingkat kepercayaan diri siswa kontrol

$S D_{1}^{2}$ : Nilai varian tingkat kepercayaan diri siswa eksperimen

$S_{2}^{2}$ : Nilai varian tingkat kepercayaan diri siswa kontrol

$N_{1} \quad$ : Jumlah sampel siswa eksperimen

$N_{2}$ : Jumlah sampel siswa kontrol

Hasil perhitungan tersebut dibandingkan dengan $t_{\text {tabel. }}$ Jika $t_{\text {hitung }}$ kecil dari $t_{\text {tabel }}$ maka dapat disimpulkan bahwa terdapat perbedaan yang signifikan antara pretest dan posttest.

\section{HASIL}

Untuk menganalisis hasil penelitian, peneliti menggunakan teknik uji beda (t-test) dengan bantuan program SPSS versi 20.00 dan Microsoft Excell 2007.

\section{Pengujian Hipotesis Pertama}

Hipotesis pertama yang diajukan dalam penelitian ini adalah terdapat perbedaan yang signifikan pada kepercayaan diri dalam belajar siswa kelompok eksperimen dan sesudah diberikan layanan penguasaan konten menggunakan model pembelajaran role playing, yang hasil perhitungannya dapat dilihat pada tabel berikut ini.

Tabel 2. Distribusi Frekuensi Pretest dan Posttest Kepercayaan Diri Siswa dalam Belajar Kelompok Eksperimen

\begin{tabular}{|c|c|c|c|c|c|}
\hline \multirow{2}{*}{ Interval } & \multirow{2}{*}{ Kategori } & \multicolumn{2}{|c|}{ Pretest } & \multicolumn{2}{c|}{ Posttest } \\
\cline { 3 - 6 } & $\mathrm{F}$ & $\%$ & $\mathrm{~F}$ & $\%$ \\
\hline 159 & $\begin{array}{c}\text { Sangat } \\
\text { tinggi }\end{array}$ & 0 & 0 & 3 & 8,57 \\
\hline $129-158$ & Tinggi & 11 & 31,42 & 19 & 54,28 \\
\hline $99-128$ & Sedang & 19 & 54,28 & 13 & 37,14 \\
\hline $68-98$ & Rendah & 5 & 14,28 & 0 & 0 \\
\hline$\leq 67$ & $\begin{array}{c}\text { Sangat } \\
\text { rendah }\end{array}$ & 0 & 0 & 0 & 0 \\
\hline \multicolumn{2}{|c|}{ Jumlah } & 35 & 100 & 35 & 100 \\
\hline
\end{tabular}

Selanjutnya, untuk melihat kondisi masingmasing kepercayaan diri siswa dalam belajar pada pretest dan posttest kelompok eksperimen dapat digambarkan pada diagram berikut.

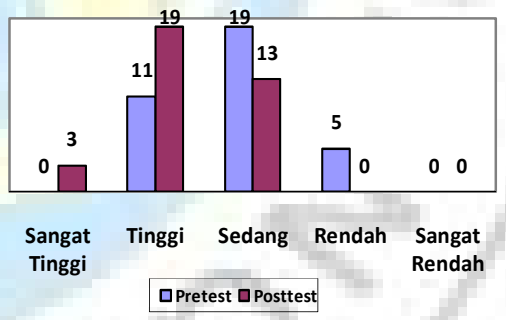

Gambar 1. Diagram Hasil Pretest dan Posttest Kepercayaan Diri Siswa dalam Belajar Kelompok Eksperimen

Sementara itu, berdasarkan hasil uji beda (t-test) diperoleh hasil sebagai berikut:

Tabel 3. Hasil Analisis Uji T-Test Perbedaan Kepercayaan Diri Siswa Dalam Belajar pada Pretest dan Posttest Kelompok Eksperimen

\begin{tabular}{|c|c|c|c|c|c|c|}
\hline $\begin{array}{c}\text { Keper } \\
\text { caya } \\
\text {-an } \\
\text { diri }\end{array}$ & $\begin{array}{c}\text { Pretest } \\
\text { dan } \\
\text { posttest }\end{array}$ & Mean & $\begin{array}{c}\text { Std. } \\
\text { Devia } \\
\text {-tion }\end{array}$ & $\mathrm{t}$ & $\mathrm{df}$ & $\begin{array}{c}\text { Sig. } \\
(2- \\
\text { taile } \\
\text { d) }\end{array}$ \\
\cline { 2 - 7 } & Postest & 121.91 & 15.725 & -4.962 & 68 & .000 \\
\cline { 2 - 7 } & 139.80 & 14.456 & & & \\
\hline
\end{tabular}


Dari hasil perhitungan tersebut diperoleh nilai Asymp. Sig. (2-tailed) lebih kecil dari taraf signifikansi $0.05 \quad(0.000<0.05)$. Dengan demikian, hipotesis pertama pada penelitian ini dapat diterima, yakni terdapat perbedaan yang signifikan pada kepercayaan diri siswa dalam belajar kelompok eksperimen sebelum dan sesudah diberi layanan penguasaan konten menggunakan model pembelajaran role playing.

\section{Pengujian Hipotesis Kedua}

Hipotesis kedua, yaitu tidak terdapat perbedaan yang signifikan pada kepercayaan diri dalam belajar siswa kelompok kontrol sebelum dan sesudah diberikan perlakuan layanan penguasaan konten tanpa menggunakan model pembelajaran role playing, yang hasil perhitungannya dapat dilihat pada tabel berikut ini.

Tabel 4. Distribusi Frekuensi Pretest dan Posttest Kepercayaan Diri Siswa dalam Belajar Kelompok Kontrol

\begin{tabular}{|c|c|c|c|c|c|}
\hline \multirow{2}{*}{ Interval } & \multirow{2}{*}{ Kategori } & \multicolumn{2}{|c|}{ Pretest } & \multicolumn{2}{c|}{ Posttest } \\
\cline { 3 - 6 }$\geq 159$ & $\begin{array}{c}\text { Sangat } \\
\text { tinggi }\end{array}$ & 0 & 0 & 1 & 2,85 \\
\hline $129-158$ & Tinggi & 12 & 34,28 & 17 & 48,57 \\
\hline $99-128$ & Sedang & 20 & 57,14 & 17 & 48,57 \\
\hline $68-98$ & Rendah & 3 & 8,57 & 0 & 0 \\
\hline$\leq 67$ & $\begin{array}{c}\text { Sangat } \\
\text { rendah }\end{array}$ & 0 & 0 & 0 & 0 \\
\hline \multicolumn{2}{|c|}{ Jumlah } & 35 & 100 & 35 & 100 \\
\hline
\end{tabular}

Selanjutnya, untuk melihat kondisi masingmasing kepercayaan diri siswa dalam belajar pada pretest dan posttest kelompok kontrol dapat digambarkan pada diagram berikut.
Sementara itu, berdasarkan hasil uji beda $(t-$ test) diperoleh hasil sebagai berikut.

Tabel 5. Hasil Analisis Uji t-test Perbedaan Kepercayaan Diri Siswa dalam Belajar pada Pretest dan Posttest Kelompok Kontrol

\begin{tabular}{|c|c|c|c|c|c|c|}
\hline $\begin{array}{c}\text { Ke } \\
\text { Percaya } \\
\text { an diri }\end{array}$ & $\begin{array}{c}\text { Pretest } \\
\text { dan } \\
\text { postest }\end{array}$ & Mean & $\begin{array}{c}\text { Std. } \\
\text { Devia } \\
\text {-tion }\end{array}$ & $\mathrm{t}$ & $\mathrm{df}$ & $\begin{array}{c}\text { Sig. } \\
(2- \\
\text { taile } \\
\text { d) }\end{array}$ \\
\cline { 2 - 7 } & Pretest & 123.42 & 16.02 & & \multirow{2}{*}{68} & $\begin{array}{c}0.18 \\
2\end{array}$ \\
\cline { 2 - 7 } & Postest & 127.91 & 12.65 & $\begin{array}{c}- \\
1.349\end{array}$ & & 28 \\
\hline
\end{tabular}

Dari hasil perhitungan tersebut diperoleh nilai Asymp. Sig. (2-tailed) lebih besar dari taraf signifikansi $0.05 \quad(0.182>0.05)$. Dengan demikian, hipotesis kedua pada penelitian ini dapat diterima, yakni tidak terdapat perbedaan yang signifikan pada kepercayaan diri siswa dalam belajar kelompok kontrol sebelum dan sesudah diberi perlakuan.

\section{Pengujian Hipotesis Ketiga}

Hipotesis ketiga yang diajukan dalam penelitian ini adalah terdapat perbedaan yang signifikan pada kepercayaan diri siswa antara kelompok eksperimen yang mengikuti layanan penguasaan konten menggunakan model pembelajaran role playing dan kepercayaan diri siswa kelompok kontrol yang mengikuti layanan penguasaan konten tanpa menggunakan model pembelajaran role playing, yang hasil perhitunganya dapat dilihat pada tabel berikut:

Tabel 6. Hasil Analisis Uji t-test Perbedaan Kepercayaan Diri Siswa dalam Belajar pada Kelompok Ekperimen dan Kelompok Kontrol Sesudah Diberikan Perlakuan

\begin{tabular}{|c|c|c|c|c|c|c|}
\hline \multirow{3}{*}{$\begin{array}{c}\text { Ke } \\
\text { Percaya } \\
\text { an diri }\end{array}$} & Posttest & Mean & $\begin{array}{c}\text { Std. } \\
\text { Devia } \\
\text { tion }\end{array}$ & $\mathrm{t}$ & df & $\begin{array}{c}\text { Sig. } \\
\text { (2- } \\
\text { taile } \\
\text { d) }\end{array}$ \\
\hline & $\begin{array}{c}\text { Ekspe- } \\
\text { rimen }\end{array}$ & 39.80 & 139.80 & \multirow{2}{*}{3.659} & \multirow{2}{*}{68} & \multirow{2}{*}{.000} \\
\hline & Kontrol & 27.91 & 127.91 & & & \\
\hline
\end{tabular}

Dari hasil perhitungan tersebut diperoleh nilai Asymp. Sig. (2-tailed) lebih kecil dari taraf signifikansi $0.05 \quad(0.000>0.05)$. Dengan demikian, hipotesis ketiga pada penelitian ini dapat diterima, yakni terdapat perbedaan yang signifikan pada kepercayaan diri siswa antara kelompok eksperimen yang mengikuti layanan penguasaan konten menggunakan model pembelajaran role playing dan kepercayaan diri siswa kelompok kontrol yang mengikuti layanan penguasaan konten tanpa menggunakan model pembelajaran role playing. 


\section{PEMBAHASAN}

Pada bagian ini akan dikemukakan pembahasan hasil temuan peneliti mengenai kepercayaan diri siswa dalam belajar melalui layanan penguasaan konten menggunakan model pembelajaran role playing.

\section{Perbedaan Kepercayaan Diri Siswa dalam Belajar Kelompok Eksperimen (Pretest dan Posttest)}

Berdasarkan pengujian hipotesis pertama, dapat disimpulkan bahwa terdapat perbedaan yang signifikan pada kepercayaan diri dalam belajar siswa kelompok eksperimen sebelum dan sesudah diberikan layanan penguasaan konten menggunakan model pembelajaran role playing, yakni terjadi peningkatan yang signifikan kepercayaan diri siswa dalam belajar kelompok eksperimen setelah diberikan perlakuan. Berdasarkan hasil penelitian Made Aprilia Dwi Kristianti (2014) dapat disimpulkan bahwa penerapan konseling kelompok dengan teknik bermain peran untuk meningkatkan percaya diri siswa kelas XI 2 SMA Negeri 3 Singaraja, ini terbukti dari peningkatan percaya diri siswa berdasarkan hasil penyebaran kuesioner percaya diri.

Kepercayaan diri menurut Enung Fatimah (2006:149) adalah sikap positif seorang individu yang memampukan dirinya untuk mengembangkan penilaian positif, baik terhadap dirinya sendiri maupun terhadap lingkungan/situasi yang dihadapinya. Kepercayaan diri yang dimaksud adalah sikap individu menerima kenyataan untuk mengembangkan penilaian positif terhadap diri dan lingkungan/situasi yang dihadapi, menyangkut dengan kepercayaan kepada kemampuan sendiri, bertindak mandiri dalam mengambil keputusan, memiliki konsep diri yang positif dan berani mengungkapkan pendapat. Dengan percaya diri, peserta didik akan mampu mengembangkan potensi yang dimilikinya dan mencapai kesuksesan belajar.

Penggunaan strategi khusus dalam proses pembelajaran maupun pemberian layanan merupakan pilihan yang tepat agar proses belajar menjadi lebih efektif. Hal tersebut juga dapat dilakukan dalam meningkatkan kepercayaan diri siswa dalam belajar. Dengan demikian, cara peneliti untuk meningkatkan kepercayaan diri siswa dalam belajar adalah dengan cara memberikan layanan penguasaan konten menggunakan model pembelajaran role playing.

Meningkatkan kepercayaan diri siswa dalam belajar merupakan salah satu tugas dan tanggung jawab guru BK atau konselor sekolah. Adapun bantuan yang diberikan dapat melalui layanan BK, diantaranya melalui layanan penguasaan konten. Pemberian layanan penguasaan konten (PKO) merupakan layanan bantuan kepada individu (sendiri ataupun kelompok) untuk menguasai kemampuan atau kompetensi tertentu melalui kegiatan belajar (Prayitno, 2012:89).
Pada penelitian ini, model pembelajaran role playing yang dilaksanakan adalah dengan membagi siswa ke dalam 2 kelompok yakni kelompok sebagai pemain peran dan kelompok pengamat. Kemudian peneliti menjelaskan tata cara dalam pelaksanaan role playing tersebut, bagi siswa yang mendapatkan kelompok peran dapat mulai memerankan peranannya masing-masing sesuai dengan materi yang telah disiapkan peneliti. Setelah Setelah selesai, kelompok pengamat memberikan penilaian terhadap kelompok yang telah bermain peran.

Keberhasilan pemberian layanan
penguasaan konten menggunakan model pembelajaran role playing diperkuat dengan hasil temuan pada hipotesis pertama yang menyatakan bahwa terdapat perbedaan yang signifikan pada kepercayaan diri dalam belajar siswa kelompok eksperimen sebelum dan sesudah diberikan layanan penguasaan konten menggunakan model pembelajaran role playing.

Berdasarkan hal yang telah dijelaskan di atas, maka layanan penguasaan konten menggunakan model pembelajaran role playing dapat diberikan dalam rangka meningkatkan kepercayaan diri siswa dalam belajar. Dengan adanya layanan penguasaan konten menggunakan model pembelajaran role playing, menjadikan siswa lebih aktif dalam mengikuti proses pembelajaran.

\section{Perbedaan Kepercayaan Diri Siswa dalam Belajar Kelompok Kontrol (Pretest dan Posttest)}

Pemberian layanan penguasaan konten untuk meningkatkan kepercayaan diri siswa pada kelompok kontrol dilakukan tanpa menggunakan model pembelajaran role playing. Dari data hasil penelitian, diketahui bahwa tidak terdapat perbedaan yang signifikan pada kepercayaan diri siswa dalam belajar kelompok kontrol sebelum dan sesudah diberi perlakuan. Dikatakan tidak signifikan karena hanya terjadi perbedaan mean sebelum dan sesudah diberi perlakuan, sementara tidak terjadinya perbedaan kategori. Perubahan tersebut dikarenakan kelompok kontrol tidak mendapat perlakuan khusus yaitu layanan penguasaan konten menggunakan model pembelajaran role playing. Berdasarkan hasil penelitian Iceu Rohayati (2011) disimpulkan bahwa bimbingan teman sebaya (peer guidance) dapat mempengaruhi percaya diri siswa, juga berbagai faktor, baik itu faktor dari dalam individu itu sendiri, yang semuanya itu tidak lepas dari proses pembelajaran, faktor dari luar individu itu sendiri seperti motivasi dan dukungan dari orang lain serta bagaimana individu berusaha meningkatkan percaya dirinya

Layanan penguasaan konten dalam meningkatkan kepercayaan diri dalam belajar siswa kelompok kontrol diberikan secara tanpa menggunakan model pembelajaran role playing, yaitu teknik ceramah dan tanya jawab. Senada 
dengan pernyataan tersebut, metode atau teknik yang digunakan dalam penyajian layanan penguasaan konten menurut Prayitno (2012:97) adalah penyajian, tanya jawab dan diskusi.

Pemberian layanan penguasaan konten tanpa menggunakan model pembelajaran role playing menjadikan guru yang lebih aktif dalam proses pembelajaran, sehingga terdapat siswa yang melakukan aktifitas lainnya. Pada hasil penelitian ini tergambarlah bahwa kurang efektifnya pemberian layanan penguasaan konten tanpa menggunakan model pembelajaran role playing. Hal ini didukung dengan hasil penelitian yang menunjukan tidak adanya perubahan signifikan sebelum dan setelah diberikan perlakuan layanan penguasaan konten pada kelas kontrol.

3. Perbedaan Kepercayaan Diri Siswa dalam Belajar Kelompok Eksperimen dan Kelompok Kontrol (Posttest)

Tujuan dari penelitian ini adalah untuk mengetahui perbedaan efektivitas layanan penguasaan konten dengan model pembelajaran role playing pada kelompok eksperimen dan layanan penguasaan konten tanpa menggunakan model pembelajaran role playing pada kelompok kontrol dalam meningkatkan kepercayaan diri siswa dalalam belajar. Hasil penelitian menunjukan bahwa terdapat perbedaan yang signifikan pada kepercayaan diri siswa yang diberi layanan penguasaan konten menggunakan model pembelajaran role playing dengan kelompok kontrol yang diberi layanan penguasaan konten tanpa model pembelajaran role playing.

Berdasarkan hasil uji statisitik menunjukan adanya perbedaan kepercayaan diri siswa dalam belajar pada kelompok eksperimen dan kelompok kontrol. Perbedaan kepercayaan diri dalam belajar siswa terjadi karena adanya perbedaan perlakuan yang diterima oleh masing-masing kelompok. Meskipun materi dan banyaknya perlakuan yang diberikan sama-sama berjumlah 4 kali. Kelompok kontrol diberikan perlakuan berbeda dari kelompok ekperimen yaitu pemberian layanan penguasaan konten tanpa menggunakan model pembelajaran role playing. Peneliti memberikan materi dan konten-konten mengenai kepercayaan diri siswa dalam belajar dengan teknik ceramah dan tanya jawab. Kemudian peneliti mempersilahkan siswa untuk bertanya apabila terdapat hal yang belum dipahami. Sebelum menjawab beberapa pertanyaan dari siswa, pertanyaan tersebut terlebih dahulu dilemparkan ke anggota kelompok lainnya dengan tujuan agar siswa-siswa yang lain ikut berpikir mengenai pertanyaan yang dikemukakan. Selama proses pembelajaran berlangsung, tidak banyak siswa yang merespon pertanyaan dari peneliti. Siswa yang aktif biasanya selalu sama pada setiap pertemuan, dan sulit untuk mendorong siswa yang lain untuk ikut aktif.

Selanjutnya, untuk kelompok eksperimen diberikan perlakuan layanan penguasaan konten menggunakan model pembelajaran role playing. Dalam pelaksanaan pembelajaran, guru hendaknya dapat membantu siswa untuk lebih mudah memahami pelajaran dan melibatkan siswa untuk lebih aktif serta menjadikan proses pembelajaran sebagai hal yang menyenangkan. Begitupun untuk guru Bimbingan dan Konseling, yang juga dapat lebih inovatif untuk menggunakan media, model ataupun strategi pembelajaran dalam pemberian layanan. Layanan penguasaan konten yang diberikan guru BK bertujuan agar siswa menguasai aspek-aspek konten (kemampuan atau kompetensi) tertentu yang berguna untuk menambah wawasan dan pemahaman, mengarahkan penilaian dan sikap, menguasai cara-cara tertentu dalam rangka memenuhi kebutuhan dan mengatasi masalahmasalahnya (Tohirin, 2011:159).

Pemilihan model pembelajaran perlu didasari oleh kesesuaian tujuan dari pembelajaran itu sendiri. Model pembelajaran role playing merupakan salah satu model dalam pembelajaran yang mengajak siswa untuk aktif, inovatif, kreatif dan menyenangkan. Kegiatan-kegiatan dalam layanan penguasaan konten menggunakan model pembelajaran role playing ini juga menjadikan hubungan sosial siswa lebih baik dan meningkatkan imajinasi siswa. Sehubungan dengan itu, Istarani (2012:70) menyatakan bahwa role playing adalah suatu pembelajaran yang bertujuan untuk membantu siswa menemukan makna di dunia sosial dan memecahkan dilema dengan bantuan kelompok, yang dalam prosesnya dapat memberikan contoh prilaku yang berguna untuk menggali perasaannya, memperoleh insprirasi dan pemahaman yang berpengaruh terhadap sikap, nilai dan persepsinya, mengembangkan keterampilan dan sikap dalam memecahkan masalah, dan mendalami pelajaran dengan berbagai cara.

\section{KESIMPULAN}

Berdasarkan data dan hasil penelitian yang telah diperoleh, maka secara khusus temuan dalam penelitian ini adalah sebagai berikut :

1. Terdapat perbedaan yang signifikan pada kepercayaan diri dalam belajar siswa kelompok eksperimen sebelum dan sesudah diberikan layanan penguasaan konten menggunakan model pembelajaran role playing.

2. Tidak terdapat perbedaan yang signifikan pada kepercayaan diri dalam belajar siswa kelompok kontrol sebelum dan sesudah diberikan 
perlakuan layanan penguasaan konten tanpa menggunakan model pembelajaran role playing.

3. Terdapat perbedaan yang signifikan pada kepercayaan diri siswa antara kelompok eksperimen yang mengikuti layanan penguasaan konten menggunakan model pembelajaran role playing dan kepercayaan diri siswa kelompok kontrol yang mengikuti layanan penguasaan konten tanpa menggunakan model pembelajaran role playing.

Hasil pengujian ketiga hipotesis dalam penelitian ini menunjukan bahwa layanan penguasaan konten menggunakan model pembelajaran role playing lebih efektif dalam meningkatkan kepercayaan diri siswa dalam belajar. Layanan penguasaan konten tanpa menggunakan model pembelajaran role playing dapat meningkatkan kepercayaan diri siswa dalam belajar, namun peningkatan rata-rata skor tidak sebanyak pada layanan penguasaan konten dengan model pembelajaran role playing.

\section{SARAN}

Berdasarkan hasil penelitian, pembahasan, dan simpulan yang telah dikemukakan, beberapa saran yang dapat diajukan sebagai tindak lanjut dari penelitian ini adalah sebagai berikut.

1. Guru bimbingan dan konseling diharapkan agar membantu dan membimbing siswa dalam meningkatkan kepercayaan diri siswa dalam belajar melalui layanan penguasaan konten menggunakan model pembelajaran role playing. Guru BK dapat memprogramkan penyelenggaraan layanan penguasaan konten secara berkesinambungan sesuai dengan kebutuhan siswa. Tentunya pelaksanaan layanan penguasaan konten dapat disesuaikan dengan berbagai model pembelajaran.

2. Kepada Dinas Pendidikan Kota Padang dapat dimanfaatkan sebagai acuan dalam pelaksanaan program pelatihan untuk meningkatkan kemampuan pengembangan keterampilan konseling guru BK se-kota Padang, terutama dalam pelaksanaan layanan penguasaan konten menggunakan model pembelajaran role playing.

3. Kepada Kepala sekolah diharapkan untuk terus mendukung program guru bimbingan dan konseling, untuk meningkatkan kualitas guru bimbingan dan konseling/konselor dengan lebih banyak lagi memberikan kesempatan pada guru bimbingan dan konseling/konselor untuk aktif mengikuti pelatihan-pelatihan yang bermanfaat dalam meningkatkan penyelenggaraan layanan bimbingan dan konseling terutama layanan pengusaan konten. Selain itu, kepala sekolah dapat meningkatkan fasilitas guru BK.

4. Bagi peneliti lainnya, perlu dilakukan penelitian yang berkaitan dengan kepercayaan diri siswa dalam belajar dengan studi lanjutan dan penggunaan strategi pembelajaran lainnya, latar belakang munculnya dan upaya pengentasannya. Selain itu hasil penelitian ini juga dapat digunakan panduan bagi penggunaan layanan bimbingan dan konseling baik secara klasikal maupun secara kelompok.

5. Bagi siswa yang sudah mengikuti layanan penguasaan konten, disarankan untuk dapat lebih berpartisipasi aktif dalam kegiatan layanan penguasaan konten selanjutnya. Untuk siswa secara keseluruhan bagi yang mengalami masalah percaya diri, agar dapat memanfaatkan layanan bimbingan dan konseling yang ada di sekolah, karena layanan penguasaan konten merupakan salah satu layanan yang dapat membantu dalam mengentaskan masalah siswa.

\section{KEPUSTAKAAN}

Agus Irianto. 2004. Statistik: Konsep Dasar, Aplikasi dan Pengembangannya. Jakarta:Prenada Media Group.

Enung Fatimah. 2006. Psikologi perkembangan peserta didik. Bandung: Pustaka setia.

Iceu Rohayati. 2011. "Program Bimbingan Teman Sebaya untuk Meningkatkan Percaya Diri Siswa (Studi Eksperimen pada Siswa SMA N 13 Bandung Kelas XI Tahun Ajaran 2010-2011)”. Jurnal: ISSN 1412-565X.

Istarani. 2012. 58 Model Pembelajaran Inovatif. Medan: Media Persada.

Kadek Suhardita. 2011. Efektifitas Penggunaan Teknik Permainan dalam Bimbingan Kelompok untuk Meningkatkan Percaya Diri Siswa. Jurnal. ISSN 1412-565X. UPI Bandung.

Made Aprilia Dwi Kristianti. 2014. "Penerapan Konseling Kelompok dengan Teknik Bermain Peran untuk Meningkatkan Percaya Diri pada Siswa SMA". e-journal Undiksa Jurusan Bimbingan Konseling Volume: 2 No 1.

Prayitno. 2012. Jenis Layanan dan Kegiatan Pendukung Konseling. Padang: BK FIP UNP.

Slameto. 2010. Belajar dan Faktor-Faktor yang Mempengaruhinya. Jakarta: Rineka Cipta.

Suharsimi Arikunto. 2010. Manajemen Penelitian. Jakarta: Rineka Cipta.

Supriyo. 2008. Studi Kasus Bimbingan Konseling. Semarang: UNNES PRESS.

Syaiful Bahri Djamarah dan Aswan Zain. 2010. Strategi Belajar Mengajar. Jakarta: Rineka Cipta. 
Tohirin. 2011. Bimbingan dan Konseling di Sekolah dan Madrasah (Berbasis Integritas). Jakarta: Rajagrafindo Persada.

Tulus Winarsunu. 2002. Statistik dalam Penelitian Psikologi dan Pendidikan. Malang: UMM Press.

Wardatul Djannah \& Ayom Yulita. 2013. Teknik Sosiodrama untuk Meningkatkan Kepercayaan Diri Siswa Kelas VIII B SMP Kristen 1 Surakarta Tahun Pelajaran 2011/2012. Jurnal Counselium, 166-185.

Wirahanteng. 2014. Meningkatkan Percaya Diri Melalui Layanan Penguasaan Konten dengan Metode Simulasi. Jurnal. ISSN 2087-3557.

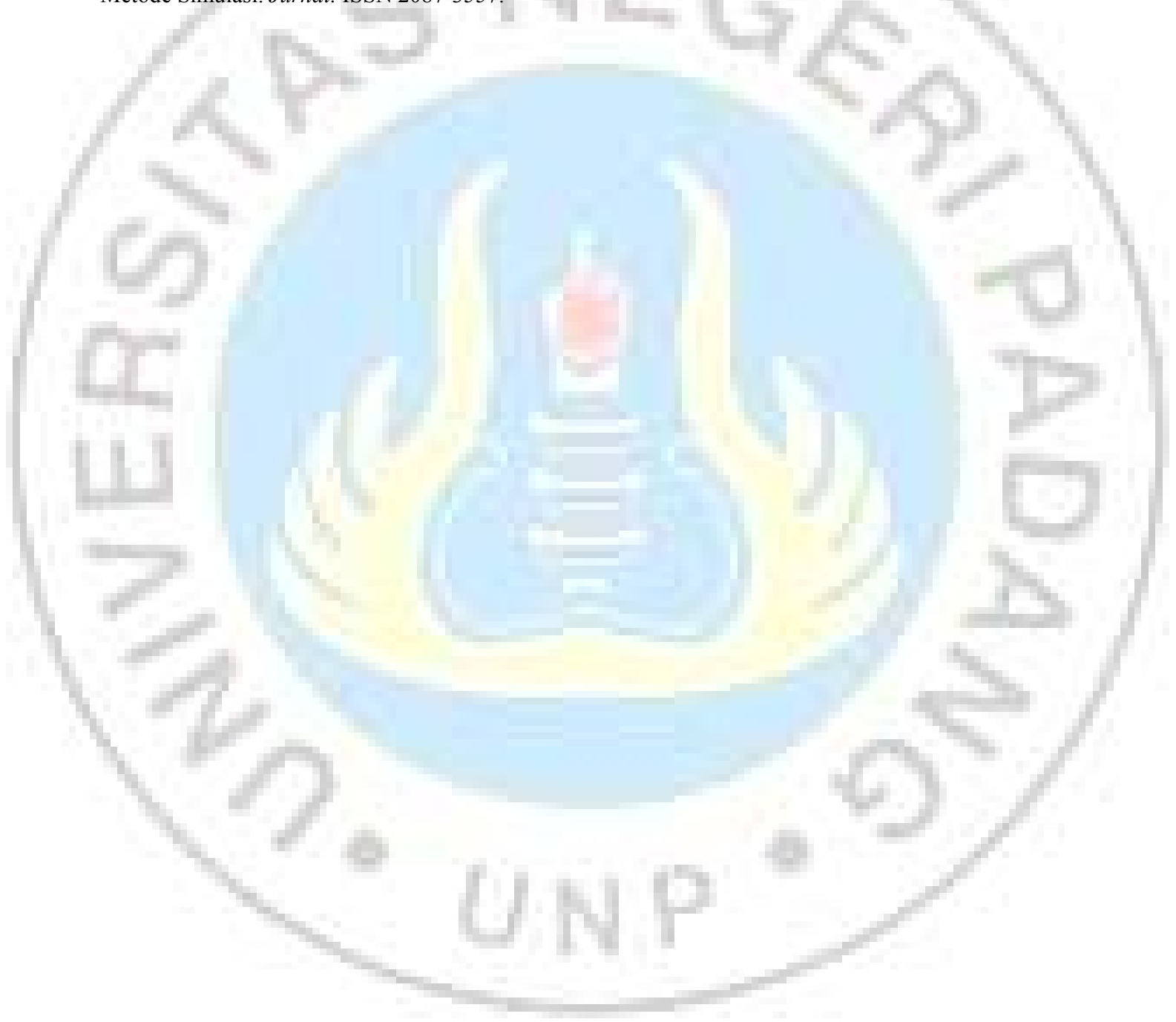

